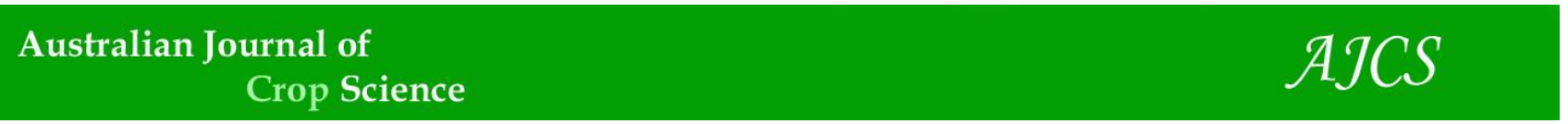

AJCS 14(12):1898-1904 (2020)

ISSN:1835-2707

doi: 10.21475/ajcs.20.14.12.2700

\title{
Combining ability in maize hybrid for yield-related traits and silage production
}

\author{
Flávia Nicácio Viana ${ }^{1}$, Jocarla Ambrosim Crevelari ${ }^{1 *}$, Gabriel Moreno Bernardo Gonçalves ${ }^{1}$, José Arantes \\ Ferreira Júnior ${ }^{1}$, Débora Evellin Gonçalves França ${ }^{2}$, Messias Gonzaga Pereira ${ }^{1}$, Antonio Teixeira do Amaral \\ Júnior ${ }^{1}$
}

\author{
${ }^{1}$ Universidade Estadual do Norte Fluminense Darcy Ribeiro, Laboratório de Melhoramento Genético Vegetal, \\ Avenida Alberto Lamego 2000, Parque Califórnia, CEP 28013-602, Campos dos Goytacazes, RJ, Brazil \\ ${ }^{2}$ Universidade Estadual do Norte Fluminense Darcy Ribeiro, Laboratório de Zootecnia, Avenida Alberto Lamego \\ 2000, Parque Califórnia, CEP 28013-602, Campos dos Goytacazes, RJ, Brazil
}

\section{*Corresponding author: jcrevelari@yahoo.com.br}

\begin{abstract}
Maize cultivars developed for silage production are desirable because ensiling enables the production of high-quality feed and, increases farmers profit. Diallel cross is an efficient and advantageous mating technique that allows the selection of the best parents and crossings. The objective of this study was to estimate the general combining ability (GCA) and specific combining ability (SCA) of hybrids and their parents and to evaluate promising hybrid crosses that can be used in breeding programs. Six genotypes were crossed in a complete diallel system. Fifteen hybrid combinations, six parents, and three commercial controls were evaluated in the 2017/2018 growing season in the north and northwest regions of Rio de Janeiro state, Brazil. Nine agronomic traits were analyzed at the silage stage: plant and ear height, stem diameter, stand, husk covering, number of cobs, husked ear weight, unhusked ear weight, and fresh mass yield. The study employed a completely randomized block design with four repetitions. The parents UENF 2210, Piranão 12, and UENF 2208 presented higher GCA values for fresh matter yield and were indicated for the generation of single cross $\left(F_{1}\right)$ hybrids. The parental combinations of UENF $2208 \times$ Piranão 12 , UENF $2208 \times$ UENF 2205 , and UENF $2209 \times$ UENF 2205 had high SCA for most of the evaluated traits and were promising for the use in breeding programs. The crosses with higher average yield were UENF $2208 \times$ Piranão 12, UENF $2210 \times$ Piranão 12, and UENF 2208 × UENF 2205.
\end{abstract}

Keywords: Diallel; Griffing method; Plant breeding; Zea mays L.

Abbreviations: GCA_general combining ability; SCA_specific combining ability; PH_plant height; EH_ear height; SD_stem diameter; STAND_stand; HC_husk covering; NE_number of ears; HEW_ husked ear weight; UEW_unhusked ear weight; FMY_fresh matter yield.

\section{Introduction}

Maize (Zea mays L.) is one of the oldest crops in the world and has wide genetic variability, allowing its cultivation in different edaphoclimatic and technological conditions (Môro and Fritsche Neto, 2015). The grains most commonly used in feed production are maize and soy.

In Brazil, during drought periods, adequate food supply to animals is limited, especially in tropical regions, and is strongly influenced by seasonal variations. In addition, forage plants do not provide sufficient nutrients to meet the demands for animal production throughout the year (Macêdo et al., 2017). Therefore, high-quality feed needs to be produced during the summer. Moreover, the feed can be stored, preserved, and given to animals, especially ruminants, to increase the efficiency of milk and meat production.

Ensiling (silage) allows production of high-quality feed and increases the potential of financial return to farmers during drought periods. Ensiling is the primary method of forage conservation, and silage is used as feed during periods of water shortage. Ensiling involves low-cost and simple equipment compared to haymaking (Edson et al., 2018; Wilkinson and Rinne, 2018), and increases forage availability in the north and northwest regions of the state of Rio de Janeiro, where the most prominent activity is livestock production.

Maize silage is the primary feed used in intensive ruminant production systems, especially in dairy farms. Silage production becomes more competitive by choosing hybrids with high yield, high digestible energy, and high fermentative capacity (Oliveira et al., 2017). The most favorable characteristics of maize hybrids used in breeding programs in Brazil are high grain and dry matter yield and high nutritional value (Marcondes et al., 2012). In addition, selecting grains with higher digestibility is crucial.

Maize genotypes are classified into three categories according to grain texture: dent, mid-dent, and flint. Dent kernels have a higher percentage of farinaceous endosperm, compared to hard endosperm genotypes (Piovesan et al., 
2011), making the former more suitable for silage production. The presence of a compact protein matrix in the vitreous portion of flint kernels limits enzymatic attack and may reduce ruminal digestibility (Majee et al., 2008).

In Brazil, there is great concern about the cultivation of maize for silage production because of the restricted availability of dent kernel cultivars with high digestibility (Pereira, 2013). In addition, suitable cultivars should have a low proportion of cobs and stalks, high digestibility of vegetative parts, and a good kernel to cob ratio (Pereira, 2013). One of the breeding strategies adopted to improve silage production and quality is inbred lines, and promising crosses produce hybrids that are superior to the original lines (Paterniani, 1974). Therefore, genetic improvement programs in Brazil should focus on selecting hybrids for silage maize production.

In this context, obtaining hybrids using diallel crosses is feasible and helps select parental lines based on the combining ability, which is essential in genetic improvement programs (Veiga et al., 2000) and allows identifying parameters that are useful for selecting parents for hybridization and development of productive hybrids (Cruz et al., 2012). The general combining ability (GCA) of the parental lines estimated from hybrid populations indicates the degree to which these lines differ from the overall GCA of the parents from the diallel population. The genetic effects of the specific combining ability (SCA) are noncumulative. Hybrid combinations with the highest SCA estimates and that include at least one parent with a favorable GCA effect are desirable (Bordallo et al., 2005).

The importance of this study for the North and Northwest fluminence region is mainly the lack of forage hybrids adapted to this region, in which livestock is one of the main agricultural activities. In general, Brazilian maize breeding programs are focused on the production of hybrids for grain production (Gomes et al., 2004). There is a lack of information regarding agronomic response, productivity and nutritional value, which is an obstacle for the selection of corn hybrids for silage production. Therefore, we aimed to investigate the available genotypes of our germplasm bank, where initially a topcross with a high number of genotypes was carried out. From that test the most adapted, productive and best-suited genotypes reproduction (Crevelari et al., 2017; Crevelari et al., 2019) were selected to proceed to the second stage of investigation. In the second stage, a diallel cross was peformed, where we had a greater possibility of crossing since we had a smaller number of genotypes.

It is worth highlighting the importance of developing specific genotypes for silage production adapted to the edaphoclimatic conditions of the north and northwest regions of the state of Rio de Janeiro. The objective of this study is to estimate the GCA and SCA for agronomic traits of hybrids and to evaluate promising hybrid crosses, selecting them for breeding programs.

\section{Results and Discussion}

\section{Analysis of variance}

There were significant differences between the plots for most agronomic characteristics (Table 1), demonstrating that the evaluated environments were distinct. There were significant differences $(p<0.01)$ in the source of variation between treatments for all nine traits, indicating the existence of genetic variability between treatments and the potential for genetic gains using these genotypes. The mean square effects of the treatments involving parents and hybrids were significant, indicating differences between genotypes in each of these two groups. There were significant effects on $\mathrm{EH}, \mathrm{NE}$, and $\mathrm{HC}$ in the commercial control.

Skonieski et al. (2014) showed that the morphological structures of maize plants grown for silage production are relevant because they affect grain quality. Considering the different treatments in crosses in the two study sites, there were significant effects on NE, HC, HEW, and UEW in the interaction $\mathrm{H} \times \mathrm{L}$.

The combined ANOVA indicated a significant effect $(p<0.01)$ on $\mathrm{HC}, \mathrm{HEW}$, and UEW in the interaction $\mathrm{T} \times \mathrm{L}$, demonstrating that the response of these genotypes to environmental changes was different and that stability and adaptability analyses and environmental stratification were feasible (Carvalho et al., 2013). This result is relevant for developing genetic improvement programs because the evaluated environments affected the expression of genotypes equally. Therefore, the use of cultivars with high adaptability is crucial for farmers and breeders (Aguiar et al., 2017).

The experimental coefficient of variation $\left(\mathrm{CV}_{\mathrm{e}}\right)$ ranged from $5.95 \%$ to $15.5 \%$, indicating that the experimental precision was acceptable for all evaluated characters. This indicates that experimental conditions under which the genotypes evaluated were reliable (Table 1). The Ministry of Agriculture, Livestock, and Supply reported that only experiments, whose $\mathrm{CV}_{\mathrm{e}}$ values are $\leq 20 \%$ should be considered for cultivar registration. This criterion is used for soybean, wheat, beans, maize, and sorghum crops (MAPA, 2012). Pimentel Gomes (2009) found that $\mathrm{CV}_{\mathrm{e}}$ below $15 \%$ is associated with high experimental accuracy and reliability. Therefore, the data obtained in this study are reliable.

For estimating the mean square effects from diallel analysis, the existence of genetic variability among the 21 hybrid combinations was demonstrated by the significant effects on the traits between treatments, and these effects were classified into GCA and SCA.

Significant effects of GCA on all traits indicated that the allelic frequency of parents was different from that of other genotypes, and some genotypes were more promising for producing superior lineages (Table 1). There was a significant effect of SCA on six of the nine traits. This result showed that lineages produced from these parents might be useful in interpopulation improvement.

There was a significant effect on a few traits in the interaction GCA $\times \mathrm{L}$, suggesting that using different parents at specific sites was not necessary. There was a significant effect on two characteristics in the interaction SCA $\times \mathrm{L}$, indicating that using site-specific hybrid combinations was not necessary, and the breeding program could make decisions based on the SCA of crosses and average traits in the two study sites.

The mean square effect of SCA was higher than that of GCA on $\mathrm{PH}, \mathrm{EH}, \mathrm{HEW}, \mathrm{UEW}$, and FMW (Table 1), demonstrating that the genetic activity and structure of the hybrids favored the manifestation of non-cumulative genetic effects. Therefore, hybridization is the best strategy for genetic improvement and obtaining genetic gains for these traits. However, the estimated square effect of GCA was significantly higher than that of SCA on SD, NE, HC, and STAND, indicating the importance of genes with cumulative 


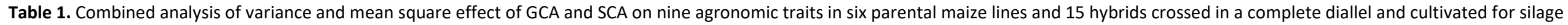
production in the 2017/2018 growing season in the municipalities of Campos dos Goytacazes and Itaocara, Rio de Janeiro, Brazil.

\begin{tabular}{|c|c|c|c|c|c|c|c|c|c|c|}
\hline \multirow{2}{*}{ Sov } & \multirow{2}{*}{ DF } & \multicolumn{9}{|c|}{ Mean Squares } \\
\hline & & $\mathrm{PH}$ & EH & SD & $\mathrm{NE}$ & $\mathrm{HC}$ & STAND & HEW & UEW & FMY \\
\hline Block/location & 6 & $0.35 * *$ & $0.20^{* *}$ & $8.89 * *$ & 3.83 & 0.19 & 3.26 & 5.97 & 1.59 & 93.28 \\
\hline Location (L) & 1 & 0.02 & $0.09 * *$ & $594.35^{* *}$ & $432.00^{* *}$ & $5.33^{* *}$ & $121.92^{* *}$ & $682.96 * *$ & $268.52^{* *}$ & $14992.02 * *$ \\
\hline Treatment (T) & 23 & $0.34^{* *}$ & $0.27^{*}$ & $5.62 * *$ & $56.83^{* *}$ & $0.31^{* *}$ & $8.06 * *$ & $64.81 * *$ & $50.24^{* *}$ & $537.73 * *$ \\
\hline Parental line (P) & 5 & $0.31^{* *}$ & $0.25^{* *}$ & $13.59^{*}$ & $91.23^{* *}$ & 0.18 & $18.87^{* *}$ & $81.34^{* *}$ & $50.30^{* *}$ & $674.33^{* *}$ \\
\hline Hybrid (H) & 14 & $0.19^{* *}$ & $0.17^{* *}$ & 2.32 & $41.62^{* *}$ & $0.3^{* *}$ & 4.23 & $18.98^{* *}$ & $17.36^{*}$ & $184.58^{* *}$ \\
\hline Control (C) & 2 & 0.01 & $0.16^{* *}$ & 3.66 & $53.37^{*}$ & $0.87^{* *}$ & 8.17 & 1.11 & 3.39 & 0.3 \\
\hline Interactions & 2 & $1.76^{* *}$ & $1.19 * *$ & 10.80 & $80.77^{* *}$ & 0.09 & 7.84 & $407.94 * *$ & $327.14 * *$ & $3205.79 * *$ \\
\hline$T \times L$ & 23 & 0.03 & 0.01 & 2.59 & 11.76 & $0.27^{* *}$ & 3.12 & $7.56^{* *}$ & $2.88^{*}$ & 64.77 \\
\hline$P \times L$ & 5 & 0.06 & 0.02 & 2.12 & 5.63 & 0.23 & 2.94 & 1.67 & 2.35 & 23.19 \\
\hline $\mathrm{H} \times \mathrm{L}$ & 14 & 0.03 & 0.01 & 2.57 & $16.69^{* *}$ & $0.26^{*}$ & 3.23 & $9.7^{* *}$ & $3.41 *$ & 75.58 \\
\hline $\mathrm{C} \times \mathrm{L}$ & 2 & 0.01 & 0.01 & 5.9 & 3.37 & 0.29 & 3.5 & 4.1 & 0.33 & 46.94 \\
\hline Residual & 138 & 0.02 & 0.01 & 2.48 & 8.78 & 0.12 & 3.15 & 3.77 & 1.69 & 48.35 \\
\hline Médias & & 2.61 & 1.59 & 16.53 & 20.91 & 4.78 & 20.26 & 13.14 & 8.51 & 47.23 \\
\hline CVe \% & & 5.97 & 6.89 & 9.54 & 14.16 & 7.22 & 8.75 & 14.78 & 15.28 & 14.72 \\
\hline \multicolumn{11}{|c|}{ Diallel analysis (ANOVA) } \\
\hline Genotype (G) & 20 & $0.35^{* *}$ & $0.26^{* *}$ & $6.05^{* *}$ & $59.81^{* *}$ & 0.25 & $8.37 * *$ & $69.33 * *$ & $48.5^{* *}$ & $616.93 * *$ \\
\hline $\mathrm{G} \times \mathrm{L}$ & 20 & 0.03 & 0.01 & 2.33 & 13.32 & $0.29 * *$ & 3.17 & 7.93 & 3.21 & 65.46 \\
\hline CGA & 5 & $0.53^{* *}$ & $0.53^{* *}$ & $13.62^{* *}$ & $167.2^{* *}$ & 0.3 & $13.96 *$ & $100.2^{* *}$ & $86.39 * *$ & $564.69 * *$ \\
\hline SGA & 15 & $0.28^{* *}$ & $0.17^{* *}$ & 3.53 & $24.02^{* *}$ & 0.24 & 6.51 & $59.04 * *$ & $35.99 * *$ & $634.35^{* *}$ \\
\hline GCA $\times L$ & 5 & 0.99 & 0.02 & 1.99 & $30.09 * *$ & $0.49 * *$ & $5.15^{* *}$ & $13.12^{* *}$ & 4.29 & 113.63* \\
\hline SCA $\times L$ & 15 & 0.01 & 0.01 & 2.44 & 7.73 & 0.22 & $2.52^{* *}$ & 6.2 & $2.85^{*}$ & 49.4 \\
\hline Residual & 120 & 0.02 & 0.01 & 2.47 & 8.09 & 0.12 & 3.21 & 3.65 & 1.59 & 47.9 \\
\hline Average & & 2.63 & 1.61 & 16.5 & 20.86 & 4.79 & 20.23 & 12.87 & 8.14 & 47.08 \\
\hline CVe \% & & 5.95 & 6.88 & 9.51 & 13.62 & 7.27 & 8.85 & 14.84 & 15.5 & 14.7 \\
\hline \multirow{2}{*}{ Mean square effect } & GCA & 0.0039 & 0.0056 & 0.1576 & 2.2373 & 0.0009 & 0.1163 & 0.6432 & 0.7875 & -1.09 \\
\hline & SCA & 0.0293 & 0.0177 & -0.1755 & 0.9804 & -0.0003 & 0.0119 & 6.4671 & 4.0996 & 67.32 \\
\hline
\end{tabular}

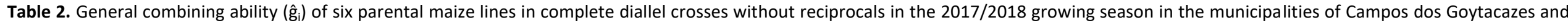
Itaocara, Rio de Janeiro, Brazil.

\begin{tabular}{cccccccccc}
\hline Parental & \multicolumn{10}{c}{ MEAN SQUARE EFFECT OF GCA } \\
\cline { 2 - 11 } genotypes & PH & EH & SD & NE & HC & STAND & HEW & UEW & FMY \\
\hline UENF 2202 & -0.12 & -0.96 & -0.21 & 0.96 & 0.05 & 0.44 & -0.05 & 0.97 & -1.78 \\
UENF 2208 & 0.13 & 0.16 & -0.53 & -0.39 & 0.02 & -0.51 & -0.48 & -1.19 & 0.68 \\
UENF 2209 & -0.06 & -0.02 & -0.31 & -2.38 & -0.13 & -0.57 & -1.83 & -1.10 & -4.71 \\
UENF 2210 & 0.06 & -0.01 & 0.57 & -0.28 & 0.03 & 0.15 & 1.84 & 1.12 & 3.50 \\
UENF 2205 & -0.05 & -0.07 & 0.56 & -0.37 & -0.01 & -0.04 & -0.33 & -0.87 & -0.15 \\
Piranão 12 & 0.036 & 0.03 & -0.08 & 2.47 & 0.03 & 0.53 & 0.85 & 1.07 & 2.46 \\
\hline
\end{tabular}

PH, plant height; EH, ear height; SD, stem diameter; NE, number of ears, HC, husk covering; STAND, number of plants at harvest; HEW, husked ear weight, UEW, unhusked ear weight; FMW, fresh matter yield. 


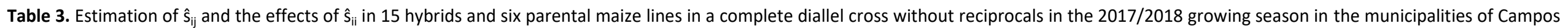
dos Goytacazes and Itaocara, Rio de Janeiro, Brazil.

\begin{tabular}{|c|c|c|c|c|c|c|c|c|c|}
\hline \multirow{2}{*}{ Hybrids } & \multicolumn{9}{|c|}{ Average effects of SCA } \\
\hline & $\mathrm{PH}$ & EH & SD & $\mathrm{NE}$ & $\mathrm{HC}$ & STAND & HEW & UEW & FMY \\
\hline UENF 2202 & -0.124 & -0.107 & -0.047 & -0.947 & -0.156 & -0.39 & -2.977 & -2.832 & -8.604 \\
\hline UENF $2202 \times$ UENF 2208 & 0.009 & -0.028 & 0.251 & 1.81 & 0.101 & 1.669 & 2.625 & 1.788 & 8.42 \\
\hline UENF $2202 \times$ UENF 2209 & 0.053 & 0.049 & 0.571 & -1.069 & -0.209 & 0.515 & 0.515 & 0.78 & 4.007 \\
\hline UENF $2202 \times$ UENF 2210 & 0.007 & 0.014 & 0.068 & -1.046 & 0.126 & -0.7 & 0.467 & 0.94 & -0.745 \\
\hline UENF $2202 \times$ UENF 2205 & 0.142 & 0.119 & -0.589 & -0.324 & 0.167 & -0.009 & 0.362 & 0.637 & 2.222 \\
\hline UENF $2202 \times$ Piranão 12 & 0.037 & 0.06 & -0.207 & 2.522 & 0.127 & -0.694 & 1.985 & 1.518 & 3.303 \\
\hline UENF 2208 & -0.268 & -0.16 & -1.067 & -3.701 & 0.04 & -1.583 & -4.855 & -3.246 & -17.173 \\
\hline UENF $2208 \times$ UENF 2209 & 0.086 & 0.011 & 0.71 & 1.41 & 0.197 & 1.348 & 1.321 & 0.879 & 4.558 \\
\hline UENF $2208 \times$ UENF 2210 & -0.05 & -0.056 & -0.381 & 1.717 & 0.013 & 0.579 & 1.458 & 0.986 & 1.173 \\
\hline UENF $2208 \times$ UENF 2205 & 0.248 & 0.186 & 1.028 & 1.155 & -0.052 & -0.676 & 1.914 & 1.197 & 9.607 \\
\hline UENF $2208 \times$ Piranão 12 & 0.243 & 0.207 & 0.525 & 1.31 & -0.341 & 0.247 & 2.392 & 1.641 & 10.588 \\
\hline UENF 2209 & -0.267 & -0.183 & -1.2 & -1.406 & 0.155 & -1.096 & -3.824 & -2.982 & -12.289 \\
\hline UENF $2209 \times$ UENF 2210 & 0.024 & 0.045 & 0.227 & 0.659 & -0.218 & -0.728 & 0.8 & 0.899 & 0.353 \\
\hline UENF 2209 × UENF 2205 & 0.206 & 0.116 & 0.65 & 1.016 & -0.02 & 0.504 & 3.395 & 2.528 & 9.5 \\
\hline UENF 2209 × Piranão 12 & 0.166 & 0.145 & 0.828 & 0.796 & -0.059 & 0.553 & 1.617 & 0.877 & 6.16 \\
\hline UENF - 2210 & -0.074 & -0.082 & -0.044 & -0.933 & 0.15 & 0.348 & -2.076 & -2.238 & -2.112 \\
\hline UENF $2210 \times$ UENF 2205 & 0.075 & 0.089 & 0.206 & 0.094 & -0.123 & -0.308 & 0.018 & 0.072 & -0.961 \\
\hline UENF $2210 \times$ Piranão 12 & 0.092 & 0.072 & -0.033 & 0.443 & $\begin{array}{l}-0.099 \\
\end{array}$ & 0.462 & $\begin{array}{l}0.409 \\
\end{array}$ & 1.578 & 4.405 \\
\hline UENF 2205 & -0.265 & -0.185 & -0.38 & -0.365 & -0.019 & 0.23 & -2.485 & -2.051 & -8.127 \\
\hline UENF $2205 \times$ P Piranão 12 & -0.14 & -0.141 & 0.049 & -1.21 & 0.067 & 0.029 & -0.718 & -0.333 & -4.114 \\
\hline Pinarão 12 & -0.199 & -0.172 & -0.581 & -1.93 & 0.152 & -0.298 & -3.342 & -2.641 & -10.171 \\
\hline
\end{tabular}

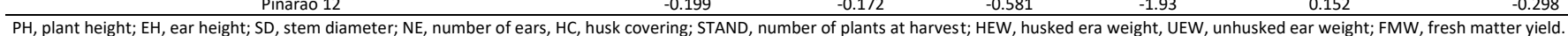

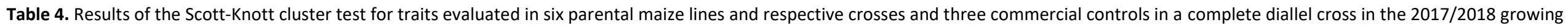
season in the municipalities of Campos dos Goytacazes and Itaocara, Rio de Janeiro, Brazil.

\begin{tabular}{|c|c|c|c|c|c|c|c|c|c|}
\hline \multirow{2}{*}{ Genotypes } & \multicolumn{9}{|c|}{ Average traits } \\
\hline & PH & EH & SD & $\mathrm{NE}$ & $\mathrm{HC}$ & STAND & HEW & UEW & FMY \\
\hline UENF 2202 & $2.27 \mathrm{~d}$ & $1.31 \mathrm{~d}$ & $16.03 a$ & $21.83 a$ & $4.75 a$ & $20.73 a$ & $9.79 b$ & $7.26 \mathrm{c}$ & $34.91 \mathrm{~b}$ \\
\hline UENF $2202 \times$ UENF 2208 & $2.65 \mathrm{~b}$ & $1.65 \mathrm{~b}$ & $16.01 a$ & $23.23 a$ & $4.96 a$ & $21.83 a$ & $14.96 a$ & $9.71 b$ & $54.40 a$ \\
\hline UENF $2202 \times$ UENF 2209 & $2.50 \mathrm{c}$ & $1.54 \mathrm{c}$ & $16.55 a$ & $18.37 \mathrm{~b}$ & 4.50a & $20.62 a$ & $11.50 \mathrm{~b}$ & $8.79 \mathrm{~b}$ & $44.59 \mathrm{a}$ \\
\hline UENF $2202 \times$ UENF 2210 & $2.58 \mathrm{~b}$ & $1.52 \mathrm{c}$ & 16.93a & $20.50 \mathrm{~b}$ & $5.00 a$ & $20.12 a$ & 15.13a & 11.18a & $48.05 \mathrm{a}$ \\
\hline UENF $2202 \times$ UENF 2205 & $2.60 \mathrm{~b}$ & $1.57 \mathrm{c}$ & $16.26 \mathrm{a}$ & $21.12 a$ & $5.00 a$ & $20.62 a$ & $12.85 \mathrm{a}$ & $8.89 \mathrm{~b}$ & $47.36 a$ \\
\hline UENF $2202 \times$ Piranão 12 & $2.59 \mathrm{~b}$ & $1.61 \mathrm{~b}$ & $16.00 \mathrm{a}$ & $26.81 a$ & $5.00 \mathrm{a}$ & $20.51 a$ & $15.65 \mathrm{a}$ & 11.70a & $51.06 \mathrm{a}$ \\
\hline UENF 2208 & $2.62 \mathrm{~b}$ & $1.77 \mathrm{~b}$ & $14.37 \mathrm{a}$ & $16.37 \mathrm{~b}$ & $4.87 \mathrm{a}$ & $17.62 a$ & $7.05 \mathrm{c}$ & $2.50 \mathrm{~d}$ & $31.27 \mathrm{c}$ \\
\hline UENF $2208 \times$ UENF 2209 & $2.78 \mathrm{~b}$ & $1.76 \mathrm{~b}$ & $16.37 a$ & $19.50 \mathrm{~b}$ & $4.87 a$ & $20.50 \mathrm{a}$ & $11.87 \mathrm{~b}$ & $6.72 c$ & $47.61 \mathrm{a}$ \\
\hline UENF $2208 \times$ UENF 2210 & $2.77 \mathrm{~b}$ & $1.71 \mathrm{~b}$ & 16.16a & $21.90 a$ & $4.85 a$ & $20.44 a$ & 15.69a & $9.05 b$ & $52.43 a$ \\
\hline UENF $2208 \times$ UENF 2205 & $2.96 a$ & $1.89 a$ & $17.56 a$ & $21.25 a$ & $4.75 a$ & $19.00 \mathrm{a}$ & 13.97a & $7.28 c$ & $57.21 a$ \\
\hline UENF $2208 \times$ Piranão 12 & $3.04 \mathrm{a}$ & $2.01 \mathrm{a}$ & $16.42 \mathrm{a}$ & $24.25 a$ & 4.50a & $20.50 \mathrm{a}$ & $15.62 \mathrm{a}$ & $9.66 \mathrm{~b}$ & $60.81 \mathrm{a}$ \\
\hline UENF 2209 & $2.24 \mathrm{~d}$ & $1.38 \mathrm{~d}$ & $14.69 \mathrm{a}$ & $14.69 \mathrm{~b}$ & $4.67 a$ & $18.00 \mathrm{a}$ & $5.37 c$ & $2.95 \mathrm{~d}$ & $25.37 \mathrm{c}$ \\
\hline UENF 2209 × UENF 2210 & $2.66 \mathrm{~b}$ & 1.63b & $16.99 a$ & $18.86 \mathrm{~b}$ & 4.46a & 19.08a & $13.67 a$ & $9.06 \mathrm{~b}$ & $46.22 \mathrm{a}$ \\
\hline UENF 2209 × UENF 2205 & $2.72 \mathrm{~b}$ & $1.64 \mathrm{~b}$ & $16.82 \mathrm{a}$ & $19.12 \mathrm{~b}$ & $4.62 a$ & $20.12 a$ & 14.09a & $8.70 \mathrm{~b}$ & $51.71 a$ \\
\hline UENF $2209 \times$ Piranão 12 & $2.77 \mathrm{~b}$ & $1.76 \mathrm{~b}$ & $16.94 a$ & $21.75 a$ & $4.62 a$ & $20.75 a$ & $13.49 \mathrm{a}$ & $8.98 \mathrm{~b}$ & $50.99 a$ \\
\hline UENF - 2210 & $2.68 \mathrm{~b}$ & $1.52 \mathrm{c}$ & $17.59 \mathrm{a}$ & $19.37 \mathrm{~b}$ & $5.00 \mathrm{a}$ & $20.87 a$ & 14.48a & $8.14 \mathrm{c}$ & $51.95 a$ \\
\hline UENF $2210 \times$ UENF 2205 & $2.72 \mathrm{~b}$ & $1.63 \mathrm{~b}$ & $17.84 a$ & $20.30 \mathrm{~b}$ & $4.68 \mathrm{a}$ & $20.02 a$ & 14.40a & $8.47 \mathrm{~b}$ & $49.46 a$ \\
\hline UENF $2210 \times$ Piranão 12 & $2.82 \mathrm{~b}$ & $1.71 \mathrm{~b}$ & $16.96 \mathrm{a}$ & $23.50 \mathrm{a}$ & $4.75 \mathrm{a}$ & $21.37 a$ & $16.96 a$ & 11.91a & $57.44 a$ \\
\hline UENF 2205 & $2.26 \mathrm{~d}$ & $1.29 \mathrm{~d}$ & $17.24 a$ & $19.75 b$ & $4.75 a$ & $20.37 a$ & $9.72 b$ & $4.36 \mathrm{~d}$ & $38.64 \mathrm{~b}$ \\
\hline UENF $2205 \times$ P Piranão 12 & $2.47 \mathrm{c}$ & $1.43 \mathrm{c}$ & $17.03 a$ & $21.75 \mathrm{a}$ & $4.87 a$ & $20.75 a$ & $12.66 \mathrm{a}$ & $8.01 \mathrm{c}$ & $45.27 \mathrm{a}$ \\
\hline Piranão 12 & $2.50 \mathrm{c}$ & $1.50 \mathrm{c}$ & $15.76 a$ & $23.87 \mathrm{a}$ & $5.00 \mathrm{a}$ & $21.00 \mathrm{a}$ & $11.21 \mathrm{~b}$ & $7.64 c$ & $41.83 \mathrm{~b}$ \\
\hline UENF - 506-11 & $2.46 \mathrm{c}$ & $1.54 \mathrm{c}$ & $16.1 a$ & $24.00 a$ & $4.37 a$ & $21.37 a$ & $14.68 \mathrm{a}$ & $10.35 a$ & $48.47 a$ \\
\hline BM 3061 & $2.41 c$ & $1.25 \mathrm{c}$ & 17.44a & $20.87 \mathrm{a}$ & $4.87 a$ & $20.62 \mathrm{a}$ & $15.42 \mathrm{a}$ & 11.65a & $48.11 \mathrm{a}$ \\
\hline AG 1051 & $2.41 c$ & $1.42 c$ & 16.63a & $18.87 \mathrm{~b}$ & $5.00 a$ & 19.37a & 15.09a & 11.13a & $48.15 a$ \\
\hline
\end{tabular}

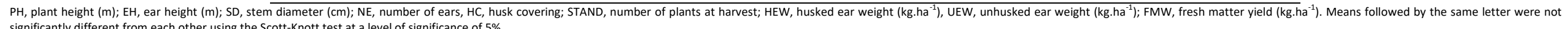
significantly different from each other using the Scott-Knott test at a level of significance of $5 \%$. 
Table 5. Description of the 6 genetypes used for diallel and the 2 controls used in the experiments, concerning genetic basis, grain type and origin.

\begin{tabular}{ccccc}
\hline Identification & Genotype & Genetic basis & Grain Type & Origin \\
\hline 1 & UENF 2202 & Population & Dent & UENF \\
2 & UENF 2208 & Lines & Dent & UENF \\
3 & UENF 2209 & Lines & Dent & Uent \\
4 & UENF 2210 & Population & Dent & UENF \\
5 & UENF 2205 & Population & Dent & UENF \\
6 & Piranão 12 & Population & UENF \\
7 & UENF 506-11* & Interpopulation hybrid & Dent & UENF \\
8 & AG 1051* & Hybrid double & Commercial \\
\hline
\end{tabular}

effects. Therefore, intrapopulation selection strategies are recommended to improve these characteristics.

The variance of cumulative effects on the genetic control of traits indicated that it was easier to select lines produced by the combination of superior parental genotypes. The variance of non-cumulative effects indicated the feasibility of using hybrid crosses "per se" with parental genotypes (Freitas Junior et al., 2006).

\section{Analysis of GCA and SCA}

GCA is related to the cumulative genetic effects and frequency of desirable parental alleles, whereas SCA is associated with differences in traits of a cross from what would be expected based on the parent's GCA as a function of the non-cumulative genetic effect combined with the effects of dominance and epistasis (Hallauer et al., 2010). The effect of GCA on $\mathrm{PH}$ and $\mathrm{EH}$ was negative in the parents UENF 2202, UENF 2209, and UENF 2205 (Table 2). In addition, the effect of GCA on SD was negative in genotypes UENF 2202, UENF 2209, and UENF 2208. The effect of GCA on NE was positive in UENF 2202 and Piranão, indicating that these genotypes had higher yields for NE. The effect of GCA on HC was negative in the parental genotypes UENF 2209 and UENF 2205, demonstrating the high degree of husk covering in harvests performed at this stage of ear development. The effect of GCA on STAND was positive in UENF 2202, UENF 2210, and Piranão 12, and these genotypes had the highest average STAND values.

It should be highlighted that the effect of GCA on FMY was positive in UENF 2210 and Piranão 12 and, consequently, FMY was increased in the crosses, in which they participated because of the presence of favorable alleles with a cumulative effect, and both HEW and UEW were increased. Therefore, these genotypes are promising in hybridizations intended to improve the analyzed traits and in genetic improvement programs because of higher average yield and higher GCA.

The effect of GCA was negative on almost all characters in genotypes UENF 2209 and UENF 2205 (Table 2). Cruz and Vencovsky (1989) reported that parents with lower frequencies of favorable alleles for the trait in question had lower $\hat{\mathrm{g}}_{\mathrm{i}}$

With regard to the effect of SCA on FMY, the crosses UENF $2208 \times$ Piranão 12, UENF $2208 \times$ UENF 2205, UENF $2209 \times$ UENF 2205, and UENF $2202 \times$ UENF 2208 had high and positive values, indicating that these combinations enhanced the effects of dominance (Table 3 ). These combinations presented higher average FMY, and the averages in these crosses were grouped in the first category (Table 4). The interactions UENF $2208 \times$ Piranão 12 and UENF $2208 \times$ UENF 2205 were the most promising.

Cluster analysis (Table 4) indicated that the following combinations were favorable: UENF $2210 \times$ Piranão 12 and UENF $2208 \times$ UENF 2210, which presented higher average FMY despite the low SCA. In the cross UENF $2210 \times$ Piranão 12 , the effect of GCA on FMY was positive in both genotypes, indicating that this combination was promising. In the cross UENF $2208 \times$ UENF 2210, the effect of GCA on FMY was very weak in UENF 2208 and weak in UENF 2210. Furthermore, the combination of the alleles from these genotypes increased FMY in the generated hybrid.

Among the 24 treatments, the parents UENF 2208 and UENF 2209 presented the lowest FMY, and cluster analysis assigned them to the category with the lowest averages. UENF 2202, UENF 2205, and Piranão 12 had intermediate FMY, whereas UENF 2210 had the highest FMY and was grouped with the hybrids with the highest FMY.

The combinations UENF $2208 \times$ Piranão 12, UENF $2210 \times$ Piranão 12, and UENF $2208 \times$ UENF 2205 were promising, with average FMY of $60.81 \mathrm{t} \mathrm{ha}^{-1}, 57.44 \mathrm{t} \mathrm{ha}^{-1}$, and $57.21 \mathrm{tha}$ 1 , respectively. The average FMY in these genotypes was higher than that considered adequate for silage production (40-50 $\mathrm{t} \mathrm{ha}{ }^{-1}$ of fresh matter), according to the recommendations of the seed companies (Piana et al., 2008).

Other crosses were promising for selecting hybrids for NE and HEW according to SCA estimates, including UENF $2202 \times$ Piranão 12, UENF $2202 \times$ UENF 2208 , and UENF $2208 \times$ UENF 2210 , with positive and high $\hat{S}_{i j}$ values for these traits.

Cruz et al. (2012) reported that SCA is associated with differences in traits of a hybrid from what would be expected based on the parent's GCA, high absolute $\hat{S}_{i j}$ values, indicating that agronomic performance is better or worse than expected. Therefore, crosses with higher positive $\hat{S}_{i j}$ for these characters should be used in breeding programs to increase grain yield.

It is worth noting that, the participation of parents UENF 2208 and Piranão 12 in these hybrid crosses, and these genotypes presented the third highest and second highest positive GCA for FMY ( 0.685 and 2.462, respectively). Worku et al. (2008) have shown that SCA should be high in hybrid crosses, and at least one parental genotype with high GCA should be included in these crosses. Therefore, the superior performance of this combination can be attributed to higher FMY, which was inherited from the parents Piranão 12 and UENF 2208, allowing an increase in FMY in the hybrids generated from these crosses. 
Moreover, the high $\hat{s}_{\mathrm{ii}}$ values indicated that the gene frequencies of these parental lines are higher (i.e., more divergent) than those of the other parents. The selection of parental lines is a crucial step in genetic improvement programs because favorable alleles for the traits of interest should be concentrated in these lines, enabling producing superior hybrids (Oliboni et al., 2012).

In hybrids with the highest average yield-related traits, at least one of the parents presented high GCA (Table 4).

\section{Materials and Methods}

\section{Plant materials}

The genotypes used in this research were selected for these crosses based on the work previously developed by the research group for improvement of forage maize (Crevelari et al., 2017; Crevelari et al., 2019). Among all materials available in the UENF germplasm bank, these stood out as good breeders and with higher yield values. Therefore, the hybrids were obtained by crossing six of these best preselected genotypes (Table 5), in a complete diallel cross without reciprocals, totaling 15 hybrid combinations. This stage was conducted at the Antônio Sarlo State School of Agriculture, in Campos dos Goytacazes, Rio de Janeiro, Brazil, in 2017. The pre-selected genotypes belong to the maize collection of the North Fluminense Darcy Ribeiro University. All genotypes produced dent kernels. Each parental pair was pollinated manually by covering spikes with polyethylene bags. Subsequently, the mature tassels were covered with a "Kraft" paper bag. The hybrids were intercrossed to obtain a sufficient number of seeds necessary to maintain hybridization.

\section{Field experiments}

The evaluation assays were performed in the 2017/2018 growing season at the Antônio Sarlo State School of Agriculture, in Campos dos Goytacazes, state of Rio de Janeiro, and at the Barra do Pomba Island Experimental Station, in Itaocara, Rio de Janeiro. According to Köppen's classification, the climate of these two regions is Aw (humid tropical), with dry winter and wet summer. The average annual temperature is approximately $23.3 \stackrel{\circ}{\circ}$, and annual rainfall is approximately $1.147 \mathrm{~mm}$ (INMET, 2019). The study adopted a completely randomized block design with four repetitions and 24 treatments (fifteen hybrids, six parents, and three commercial controls). The commercial controls were UENF 506-11, BM 3061, and AG 1051.

The experimental unit consisted of a crop row with a length of $4 \mathrm{~m}$, an inter-row spacing of $1 \mathrm{~m}$, and an inter-plant spacing of $0.2 \mathrm{~m}$. The harvests were performed by cutting the plants at $20 \mathrm{~cm}$ from the ground when $50 \%$ of the ears reached the silage stage. A practice adopted in the field to confirm the silage stage is observing the kernel milk line and harvesting the ears when $1 / 3$ to $2 / 3$ (average of $1 / 2$ ) of the kernel is filled with starch, i.e. the kernel consistency is changing from the dough to the dent stage.

\section{Agronomic traits evaluated}

Nine agronomic traits were evaluated, including six characters in six plants randomly chosen in each plot, and six traits in the entire study area. The traits analyzed in each plot were plant height $(\mathrm{PH})$, measured from ground level to the tassel insertion node $(\mathrm{m})$; ear height $(\mathrm{EH})$, measured from ground level to the node of the upper ear $(\mathrm{m})$; stem diameter (SD), measured randomly in the first internode above the ground $(\mathrm{mm})$. The traits evaluated in the study area were the stand (STAND), which is total number of plants at harvest time; husk covering $(\mathrm{HC})$, which was evaluated using a grading scale ranging from 1 to 5 , in which 1 is significant kernel exposure with low husk covering and 5 is completely protected kernels; number of ears (NE), which is the total number of harvested ears; husked ear weight (HEW), obtained by weighing all ears with husks (ton ha ${ }^{-1}$ ); unhusked ear weight (UEW), determined by weighing all ears without husks (ton ha ${ }^{-1}$ ); fresh matter yield (FMY) from all plants in each plot, which were harvested and weighed using a dynamometer scale (ton.ha ${ }^{-1}$ ).

\section{Statistical analysis}

Data were subjected to individual analysis of variance (ANOVA) in each experimental station. The joint analysis in both stations was performed after finding the homogeneity of the residual variances. Averages were grouped using the Scott-Knott test at a level of significance of $5 \%$. A combined ANOVA was performed according to the equation:

where:

$$
Y_{i j k}=\mu+(\mathcal{B} / \mathcal{A})_{j k}+\mathcal{G}_{i}+\mathcal{A}_{i}+\mathcal{G}_{\mathcal{A}_{i j}}+\mathcal{E}_{i j k}
$$

$Y_{i j k}$ is the observation in the $\mathrm{k}^{\text {th }}$ block evaluated in the $\mathrm{i}^{\text {th }}$ genotype and $\mathrm{j}^{\text {th }}$ environment; $\mu$ is the overall mean of the assay;

$(\mathcal{B} / \mathcal{A})_{j k}$ is the effect of block k on environment $\mathrm{j}$;

$\mathcal{G}_{i}$ is the fixed effect of genotype $\mathrm{i}$;

$\mathcal{A}_{i}$ is the random effect of environment $\mathrm{j}$;

$\mathcal{G}_{\mathcal{A}} \mathcal{A}_{i j}$ is the effect of the interaction between genotype $\mathrm{i}$ and environment j; and

$\mathcal{E}_{\boldsymbol{i} \boldsymbol{j} \boldsymbol{k}}$ is the random error associated with observation $Y_{\mathrm{ijk}}$. GCA and SCA were analyzed using method 2 (progenitors + F1 without reciprocals) of the diallel analysis proposed by Griffing (1956), which includes $p(p+1) / 2$ combinations. The statistical model used in the analysis was:

where:

$$
Y_{i j}=\mu+g_{i}+g_{i}+\delta_{i j}+\varepsilon_{i j}
$$

$Y_{i j}$ is the mean value of hybrid $(i \neq j)$ or parent $(i=j)$;

$\mu$ is the overall mean;

$\mathcal{g}_{i}$ and $g_{j}$ are the effects of the GCA of the $\mathrm{i}^{\text {th }}$ or $\mathrm{j}^{\text {th }}$ parent;

$\mathcal{S}_{i j}$ is the effect of the SCA of crosses between parents of

order $\mathrm{i}$ and $\mathrm{j}$; and

$\mathcal{E}_{i j}$ is the mean experimental error of observation of order $\mathrm{ij}$.

Statistical analyses were performed using GENES software (Cruz, 2013).

\section{Conclusions}

The evaluated germplasm has the potential for selecting parental maize lines for producing high-quality silage and can be used for grain production through lines derived from superior genotypes.

The parents UENF 2210, Piranão 12, and UENF 2208 had the highest general combining ability for fresh matter yield and are indicated for producing open-pollinated varieties for silage production or be used in other crosses.

The results of cluster analysis indicated that the most promising hybrids were the crosses UENF $2208 \times$ Piranão 12 , 
UENF $2210 \times$ Piranão 12, and UENF $2208 \times$ UENF 2205, which presented average yields of $60.81 \mathrm{t} \mathrm{ha}^{-1}, 57.44 \mathrm{t} \mathrm{ha}^{-1}$, and $57.21 \mathrm{t} \mathrm{ha}^{-1}$, respectively, and these values were higher than those in the commercial control.

\section{Acknowledgements}

The authors are grateful to the Research Support Foundation of Rio de Janeiro State (FAPERJ) for their financial support. This study was financed in part by the Coordenação de Aperfeiçoamento de Pessoal de Nível Superior - Brasil (CAPES) - Finance Code 001

\section{References}

Aguiar G, Streck E, Facchinello P, Goulart C, Perin L, Magalhães Júnior, A (2017) Interação genótipo x ambiente no desempenho produtivo de linhagens de arroz irrigado (Oryza sativa L.) no Rio Grande do Sul. Revista da Jornada de Pós-Graduação e Pesquisa-Congrega Urcamp. 19121923.

Bordallo PN, Pereira MG, Amaral Júnior AT, Gabriel APC (2005) Análise dialélica de genótipos de milho doce e comum para caracteres agronômicos e proteína total. Hort Bras. 23: 123-127.

Carvalho EV, Afférri FS, Peluzio JM, Rotili EA, Dotto MA, Santos WF (2013) Estratificação e dissimilaridade ambiental em genótipos de milho no Tocantins, com adubação e safras distintas. Comun Sci. 4: 277-284.

Crevelari JA, Durães NNL, Bendia LCR, Silva AJ, Pereira MG (2017) Prediction of genetic gains and correlations in corn hybrids for silage. Aust J Crop Sci. 11: 1411-1417.

Crevelari JA, Pereira MG, Azevedo FHV, Vieira RAM (2019) Genetic improvement of silage maize: predicting genetic gain using selection indexes and best linear unbiased prediction. Rev Ciênc Agron. 50: 197-204.

Cruz CD, Regazzi AJ, Carneiro PC (2012) Métodos biométricos aplicados ao melhoramento genético. Viçosa: UFV 4: 378.

Cruz CD, Vencovsky R (1989) Comparação de alguns métodos de análise dialélica. Rev Bras Genét. 12: 425-436.

Cruz CD (2013) Genes - a software package for analysis in experimental statistics and quantitative genetics. Acta Sci Agron. 35: 271-276.

Edson C, Takarwirwa NN, Kuziwa NL, Stella N, Maasdorp B (2018) Effect of mixed maize-legume silages on milk quality and quantity from lactating smallholder dairy cows. Trop Anim Health Pro. 50: 1255-1260.

Freitas Junior SP, Amaral Júnior AT, Pereira MG, Cruz CD, Scapim CA (2006) Capacidade combinatória em milho pipoca por meio de dialelo circulante. Pesq Agropec Bras. 41: 1599-1607.

Griffing BA (1956) Concept of general and specific combining ability in relation to diallel crossing systems. Aust J Biol Sci. 9: 463-493.

Hallauer AR, Carena JM, Miranda Filho JB (2010) Quantitative genetics in maize breeding. New York: Springer. 664.
INMET - Instituto Nacional de Meteorologia (2019). Available at: <http://www.inmet.gov.br/projetos/rede/pesquisa/instru cao.html>. Accessed on April 12, 2019.

Macêdo AJS, Santos EM, Oliveira JS, Perazzo AF (2017) Microbiology of silages: literature review. Rev electron vet. 18: 1-11.

Majee DN, Shaver RD, Coors JG, Sapienza D, Lauer JG (2008) Relationships between kernel vitreousness and dry matter degradability for diverse corn germplasmll. Ruminal and post-ruminal degradabilities. Anim Feed Sci Technol. 142: 259-274.

MAPA - Ministério da Agricultura, Pecuária e Abastecimento (2012). Requisitos mínimos para determinação do valor de cultivo e uso de feijão para inscrição no registro nacional de cultivares - RNC. Available at: $<$ https://docplayer.com.br/66079207-Ministerio-daagricultura-pecuaria-e-abastecimento.html>. Accessed on April 4, 2019.

Marcondes MM, Neumann M, Marafon F, Rosário JG, Faria MV (2012) Aspectos do melhoramento genético de milho para a produção de silagem. Appl Res \& Agrotec. 5: 173192.

Môro GV, Fritsche Neto R (2015) Importância e usos do milho no Brasil. In: Borem A, Galvão JC C, Pimentel MA. Milho do plantio à colheita. Viçosa: UFV

Oliboni R, Faria MV, Neumann M, Battistelli GM, Tegoni RG, Resende JTVD (2012) Genetic divergence among maize hybrids and correlations with heterosis and combining ability. Acta Sci Agron. 34: 37-44.

Oliveira IL, Lima LM, Casagrande DR, André M, Lara S, Bernardes TF (2017) Nutritive value of corn silage from intensive dairy farms in Brazil. R Bras Zootec. 46: 494-501.

Paterniani E (1974) Estudos recentes sobre heterose. Fundação Cargill: 36.

Pereira MN (2013) Milho e a silagem. Revista Balde Branco 585: 36-38.

Piana AT, Silva PRF, Bredemaeier C, Sangoi L, Vieira VM, Serpa MS, Jandrey DB (2008) Densidade de plantas de milho híbrido em semeadura precoce no Rio Grande do Sul. Cienc Rural. 38: 2608-2612.

Pimentel GF (2009) Curso de estatística experimental. Piracicaba: Fealq 15: 451.

Piovesan V, Oliveira V, Gewehr CE (2011) Milhos com diferentes texturas de endosperma e adição de alfaamilase na dieta de leitões. Cienc Rural. 41: 2014-2019.

Skonieski FR, Nörnberg JL, Kessler JD, David DB, Azevedo EB, Brüning G, Pimentel CMM (2014) Corn plant arrangement and its effect on silage quality. R Bras Zootec. 43: 114-119.

Veiga RD, Ferreira DF, Ramalho MAP (2000) Eficiência dos dialelos circulantes na escolha dos genitores. Pesq Agropec Bras. 33: 1395-1406.

Wilkinson JM, Rinne M (2018) Highlights of progress in silage conservation and future perspectives. Grass Forage Sci. 73: 40-52.

Worku M, Banziger M, Friesen D, Erley GSE, Horst WJ, Vivek BS (2008) Relative importance of general combining ability and specific combining ability among tropical maize (Zea mays $L$.) inbreds under contrasting nitrogen environments. Maydica 53: 279-288. 